\title{
Efficacy of Withania somnifera on lipid profile of endosulfan induced toxicity in Swiss albino mice
}

\author{
Sanjeev Kumar Jha \\ Department of Zoology, Patna University, Patna (Bihar), India \\ Dilip Kumar Paul* \\ Department of Zoology, Patna University, Patna (Bihar), India \\ *Corresponding author. Email: dkpaul.pat31@gmail.com
}

\author{
Article Info \\ https://doi.org/10.31018/ \\ jans.v12i3.2354 \\ Received: August 12, 2020 \\ Revised: September 8, 2020 \\ Accepted: September 12, 2020
}

How to Cite

Jha, S.K. and Paul, D.K. (2020). Efficacy of Withania somnifera on lipid profile of endosulfan induced toxicity in Swiss albino mice. Journal of Applied and Natural Science, 12(3): 454 - 459. https://doi.org/10.31018/jans.v12i3.2354

\begin{abstract}
India is an agrarian country with crops cultivated at a huge scale. Pesticides in recent times have caused serious health hazards in the population which are widely used by the farmers for the better yield of crops. Endosulfan is an organochlorine pesticide, which is widely used by the farmers. But, in the present times, it has caused serious health hazards in the exposed population causing various diseases, including cancer. Hence, the present study on animal aims to observe the protective effect of Withania somnifera against endosulfan induced toxicity in Swiss albino mice. Endosulfan at the dose of $3 \mathrm{mg} / \mathrm{Kg}$ body weight per day was administered orally to Swiss albino mice for 4 weeks. Then after, $W$. somnifera at the dose of $1000 \mathrm{mg} / \mathrm{Kg} \mathrm{b.w}$. was orally administered for 4 weeks. Mice were sacrificed after the completion of the entire treatment. After dissection, the blood samples were collected for biochemical assay, especially for lipid profile analysis. The lipid profile study showed inclination in the Total cholesterol level $(117 \pm 6.686 \mathrm{mg} / \mathrm{dl})$, Cholesterol (LDL) $(78.83 \pm 4.151 \mathrm{mg} / \mathrm{dl})$, level and Triglycerides level $(60.83 \pm 2.613 \mathrm{mg} / \mathrm{dl})$, while declination in Cholesterol $(\mathrm{HDL})(13.50 \pm 1.33 \mathrm{mg} / \mathrm{dl})$, level after Endosulfan exposure. But, upon $W$. somnifera treatment to the endosulfan treated group showed significant $(p<0.001)$ normalisation in the lipid profile levels. Therefore, it was concluded that $W$. somnifera played a vital role to control the endosulfan induced toxicity.
\end{abstract}

Keywords: Endosulfan, Efficacy, Hyperlipidaemia, Swiss albino mice, Withania somnifera

\section{INTRODUCTION}

India is an agriculture-based country with a production of the crops at very large scale. But, unfortunately, due to the pests, there is significant damage in crop production. The pest burden is increasing every year due to the appearance of new pests and diseases (Rajendran, 2003; Pimentel 1995). Among all types of pesticides present, organochlorines have proven more mortality of pests or are the best to be used in the pest management (Jayaraj et al., 2016; Akhtar 2009; Gupta 2004).

Endosulfan (hexachloro-hexahydro-methano-benzodi oxathiepinoxide) is an organochlorine (OC) insecticide belonging to class cyclodiene. It is a cyclic sulphurous acid ester with a molecular formula $\mathrm{C}_{9} \mathrm{H}_{6} \mathrm{O}_{3} \mathrm{Cl}_{6} \mathrm{~S}$ and molecular weight 407. Despite its life-threatening toxic effects, endosulfan continues to be one of the most widely used agricultural pesticides, largely in the developing countries, due to its high efficacy, low cost and environmental stability (Coutselinis et al., 1976;
Yadla et al., 2013). It is easily absorbed in the gastrointestinal tract, lungs and skin and exposure through various routes and is very hazardous. Commercially produced endosulfan consists of two isomers $\alpha$ endosulfan and $\beta$ endosulfan. Both these forms have been proved to be genotoxic to human gonads (ATSDR, 2000 and Helle et al., 2002). It has been classified by the World Health Organization (WHO) as Class II - moderately hazardous to human health. However, the United States' Environmental Protection Agency (EPA) rates endosulfan as Category lb - highly hazardous compound (WHO, 2005; USEPA 2010). Evidence of the threats to human health posed by endosulfan are abundant, and the chemical has been banned outright or severely restricted in a number of countries as a result. Independent of $L D_{50}$ results, these threats warrant the immediate upgrading of endosulfan to WHO Class I b (Pradhan et al., 1997; EPA 2002; Yavuz et al., 2007; Wilson et al., 2014; Lee et al., 2015). 
Ashwagandha (Withania somnifera, WS), belongs to the family Solanaceae, and is known to be an Ayurvedic herb worldwide for its numerous beneficial health activities since ancient times. It is widely used for the treatment of various diseases such as epilepsy, depression, arthritis, diabetes, and palliative effects such as analgesic, rejuvenating, regenerating, and growthpromoting effects. It has a multifarious effect on vital organs of the body (Pratte et al., 2014; Mirjalili et al., 2009; Rai et al., 2016; Devi et al., 1992; Kumar et al., 2015; Satyavati et al., 1976). Hence, the present work was aimed to study the protective role of $W$. somnifera against endosulfan induced toxicity in Swiss albino mice.

\section{MATERIALS AND METHODS}

Ethical approval: Ethical approval was taken from the Post Graduate Research Council (PGRC) of Patna University, Patna with no. PGRC No. Acad - / 464, serial No. 7, dated 12/02/2007.

Animals: Twenty-four Swiss albino mice ( $28 \mathrm{~g}$ to $32 \mathrm{~g}$ ) were obtained from the animal laboratory of Dr. A. Nath, Department of Zoology, Patna University, Patna, India. The research work was approved by the Post Graduate Research Council of the Patna University. Food and water to mice were provided ad libitum (prepared mixed formulated feed by the laboratory itself). Animals were maintained in colony rooms with $12 \mathrm{hrs}$ light/dark cycle at $22 \pm 2{ }^{\circ} \mathrm{C}$.

Chemicals: The commonly used pesticide- endosulfan was obtained (Excel India Pvt. Ltd. Mumbai with EC $35 \%$ ). The pesticide was prepared to $3 \mathrm{mg} / \mathrm{Kg} \mathrm{b.w}$, which was administered orally to mice for 4 weeks. Commercially available kit for chemical analyses like Serum Cholesterol, HDL, LDL Cholesterols and Triglyceride were used of crest coral clinical system, Goa, India.

Plant material: The fresh, dried rhizome of $W$. somnifera (WS) (Ashwagandha) was purchased from the herbal store in Patna, and aqueous extract was made by dissolving it in distilled water using by mortal and pistal. The dose was finally made to $1000 \mathrm{mg} / \mathrm{kg}$ body weight for oral administration.

Experimental Design: In the present study 24 mice (18 endosulfan treated and 6 as control mice) were taken and divided into groups - control (untreated group), endosulfan treated and $W$. somnifera treated. The endosulfan at the rate of $3 \mathrm{mg} / \mathrm{kg}$ body weight daily were administered orally for 4 weeks. To this endosulfan treated group aqueous extract of WS at the rate of $1000 \mathrm{mg} / \mathrm{kg}$ body weight was administered for 4 weeks. After the completion of the experiment blood samples were collected by orbital sinus puncture method and then serum was extracted for lipid profile analysis.
Statistical analysis: Results are presented as mean \pm S.D and total variation present in a set of data was analyzed through one-way analysis of variance (ANOVA). The difference among means has been analyzed by applying Dunnet's ' $\mathrm{t}$ ' test at $99.9 \% \quad(p<$ 0.001) confidence level. Calculations were performed with the GraphPad Prism Program (GraphPad Software, Inc., San Diego, USA).

\section{RESULTS AND DISCUSSION}

The lipid profile study showed inclination in the total cholesterol level $(117 \pm 6.686 \mathrm{mg} / \mathrm{dl})$, cholesterol (LDL) $(78.83 \pm 4.151 \mathrm{mg} / \mathrm{dl})$, level and triglycerides level $(60.83 \pm 2.613 \mathrm{mg} / \mathrm{dl})$, while declination in cholesterol (HDL) $(13.50 \pm 1.33 \mathrm{mg} / \mathrm{dl})$ level after Endosulfan exposure to mice. But, after WS treatment total cholesterol levels $(90 \pm 5.23 \mathrm{mg} / \mathrm{dl})$, LDL cholesterol levels $(54.67 \pm 3.75 \mathrm{mg} / \mathrm{dl})$ and triglycerides levels show decreased $(41 \pm 2.066 \mathrm{mg} / \mathrm{dl})$ in the levels while there was significant $(P<0.001)$ increase in the HDL cholesterol levels $(20.83 \pm 1.77 \mathrm{mg} / \mathrm{dl})$ denoting the protective effects (Fig.1,2,3 and 4).

Lipids are an important component of the living system as it holds in the central position in the metabolism of various functions of the body such as precursor of steroid hormones and is an important constituent of the membrane which maintains the fluidity and fragility (Shell, 1961; Lehninger, 1975; Suhail et al., 1988). They are mainly synthesized in the liver, while biochemical parameters such as lipid profile are the important indicator of the status of internal metabolic function of the body. Most of the pesticides usually cause a deleterious effect on the membrane causing serious damage to them (Agrahari and Gopal, 2009). The plethora of studies have been carried out which shows the impact of pesticides on the biochemical parameters of different fishes (Pant and Singh, 1983; Bhushan et al., 2002; Mohamed and Gad, 2008; Jenkins et al., 2003; Rajamanickam and Muthuswamy 2008; Yekeen and Fawole, 2011) and on bacteria (Saravanan et al., 2011).

In the present study, endosulfan caused significant $(P<0.001)$ hyperlipidemia in the exposed mice as it had caused hepatotoxicity in them, leading to malfunctions in cholesterol synthesis and storage in the liver. Although the liver is the vital organ of the body which detoxifies the toxicity of the pesticides but to regulate the function, it requires lots of energy for the detoxification. Lipid metabolism is activated by due to which biosynthesis of different classes of lipids takes place. Endosulfan, unfortunately, enhances the levels of lipid profile parameters such as cholesterol and triglyceride levels. Hence, it can be speculated that increased lipid profile is one of the compensatory mechanisms of the animal to detoxify the pesticide toxicity impact. The 
Total Cholesterol

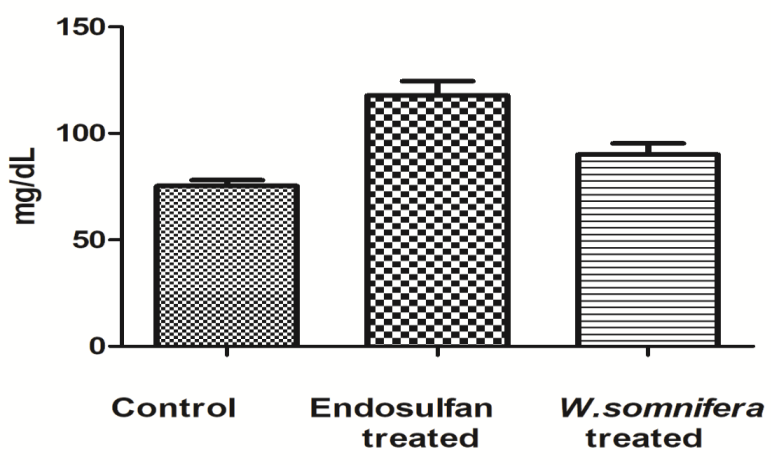

Fig.1. Effect of WS on Endosulfan treated group showing total cholesterol levels $(n=6$, values are mean $\pm S . D)$.

\section{Cholesterol (LDL)}

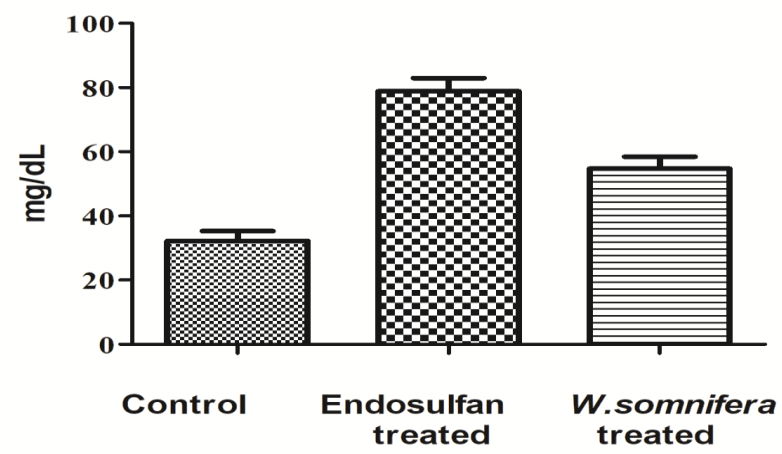

Fig.3. Effect of WS on Endosulfan treated group showing cholesterol $L D L$ levels ( $n=6$, values are mean $\pm S . D)$.

inclination in serum lipid content (total cholesterol level $(117 \pm 6.686 \mathrm{mg} / \mathrm{dl})$, cholesterol (LDL) $(78.83 \pm 4.151 \mathrm{mg} /$ dl) level; triglycerides level $(60.83 \pm 2.613 \mathrm{mg} / \mathrm{dl})$, while Cholesterol (HDL) levels as $(13.50 \pm 1.33 \mathrm{mg} / \mathrm{dl})$ resulting in hyperlipidaemia is certainly due to stressinduced by pesticide poisoning for longer periods. The test animals in the present study were observed to be restless throughout the exposure period. They were in constant fast movements aided by muscular action. Lots of extra energy was required to minimize the stress induced by endosulfan. The observed hyperlipidaemia during the present investigation may be also due to impairment in the membrane organization and damage to the liver (Alva et al., 2012). Various studies have observed the impact of pesticide on increased cholesterol levels. A study has also reported the increased level of serum cholesterol levels due to phenol induced toxicity in Oreochromis niloticus causing impairment in the membrane organization (Gad and Saad 2008; Vinson et al., 2001). Endosulfan also causes oxidative damage to the membrane due release of ROS leading to lipid peroxidation (Hincal et al., 1995; El-Shenawy 2010; Oliveira et al.,2017). This altogether causes the onset of pathogenesis, causing disease in the animal (Di Rosa et al. 1971; Kobliakov

\section{Cholesterol (HDL)}

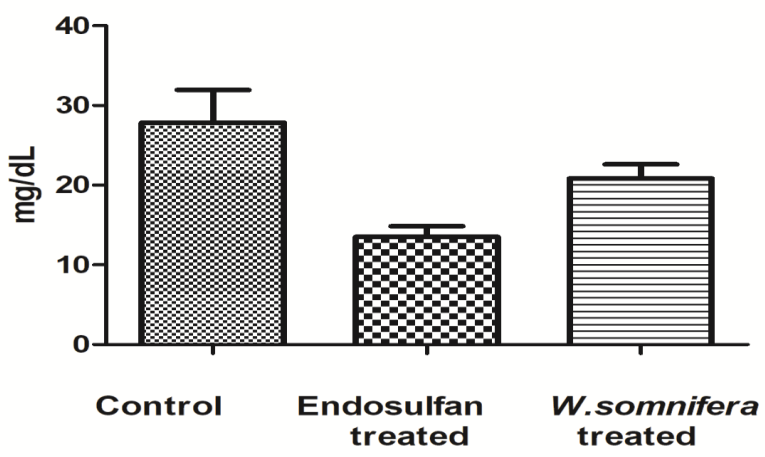

Fig.2. Effect of WS on Endosulfan treated group showing cholesterol $H D L$ levels ( $n=6$, values are mean $\pm S . D$ ).

\section{Triglycerides}

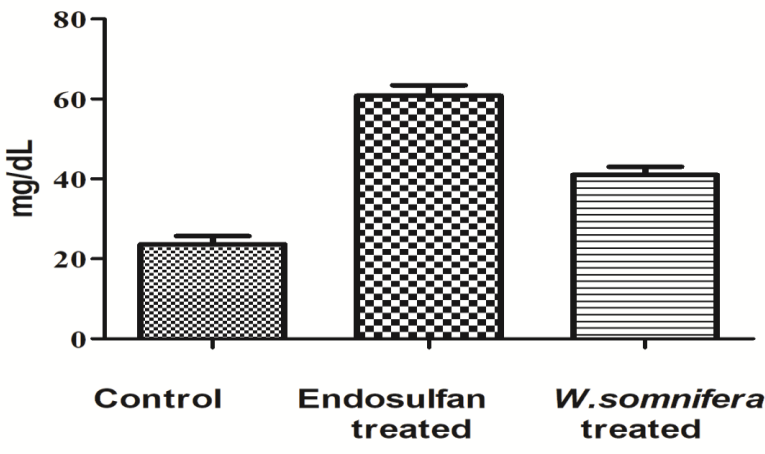

Fig.4. Effect of WS on Endosulfan treated group showing triglycerides levels ( $n=6$, values are mean $\pm S$.D.)

et al.,2001; Sood et al. 2009).

Endosulfan is a known xenoestrogen which causes severe damage to the membrane due to lipid peroxidation. The depletion of the lipids from the membrane makes the blood more viscous, causing the risk of cardiovascular disease. Hence, increased lipid profile parameters can lead to the cause of atherosclerosis and cardiovascular disease. In the present study also, there were significant changes in lipid profile parameters such as an increase in the total cholesterol, LDL cholesterol and Triglycerides while the decrease in the $\mathrm{HDL}$ cholesterol hence correlates the abovementioned pathway.

Thus, there are multiple possible pathways that might lead to selective alteration in rates of synthesis or metabolism of some classes of serum lipids. Lipid profile abnormalities play a significant role in atherosclerosis and cardiovascular disease. The findings of the present investigation indicate that exposure to endosulfan alters the metabolism of cholesterol and thus increases the risk of cardiovascular disease and atherosclerosis in mice (Vandenberg 2020; Xu et al., 2017).

Medicinal plants have a potent protective effect in controlling the hyperlipidemic effect (Deokar, 1998; Cuvelier et al., 1992; Dongmo et al., 2019; Wu et al., 
2019). In the present study, there was a significant restoration in the lipid profile levels such as total cholesterol levels $(90 \pm 5.23 \mathrm{mg} / \mathrm{dl})$, LDL cholesterol levels $(54.67 \pm 3.75 \mathrm{mg} / \mathrm{dl})$, triglycerides levels $(41 \pm 2.066 \mathrm{mg} /$ dl) and HDL cholesterol levels $(20.83 \pm 1.77 \mathrm{mg} / \mathrm{dl})$ due to WS rhizome extract treatment. The active ingredient Withaferin A in WS plays a vital role as the cholesterol -lowering effect as it increases the excretion of cholesterol and bile acids through faecal sterol excretion. The enhanced faecal neutral sterol excretion could be due to the higher fiber content in WS root. Various studies on dietary phytoconstituents of WS rhizome revealed that the dietary fibers are effective in depressing the absorption of exogenous cholesterol from micelles through increased resistance for diffusion in the aqueous luminal medium (Vahouny et al., 1980; Arjmandi et al., 1992; Moundras et al., 1997; Duangjai and Saokaew 2018; Visavadiya et al., 2007 and Duangjai, et al., 2019; Teymouri et al., 2019). Due to greater hydrophobicity, phytosterols have a greater affinity for micelles rather than for the cholesterol. The displaces the intestinal cholesterol from micelles to reduce cholesterol absorption (Miettinen and Gylling, 1999; Ikeda and Sugano, 1998). The consequent reduction in hepatic cholesterol level leads to a compensatory increase in endogenous cholesterol synthesis (Miettinen and Gylling, 1999). The decrease in the triglyceride levels due to WS may be attributed to the fibre contents of the WS which decreases the intestinal transit time for cholesterol and carbohydrate absorption (Ebihara and Schneeeman, 1989) causing decreased hepatic lipogenesis and reduction in hepatic and plasma triglyceride concentrations (Mamo et al., 1991). Hence, from the entire study, it can be concluded that WS plays a vital role to combat the deleterious effect of endosulfan as WS protects cardiovascular functions.

\section{Conclusion}

Endosulfan caused a deleterious effect on the lipid profile of the Swiss albino mice at the dose of $3 \mathrm{mg} / \mathrm{Kg}$ b.w but after the treatment of rhizome extract of WS at the dose of $1000 \mathrm{mg} / \mathrm{Kg} \mathrm{b.w}$, there was a significant restoration in the lipid profile levels such as in the total cholesterol, LDL cholesterol, HDL cholesterol and triglycerides levels. Thus, W.somnifera possessed antihyperlipidaemic activity controlling the cardiovascular disorders caused by the pesticide-induced toxicity.

\section{ACKNOWLEDGEMENTS}

The authors are thankful to the Department of Zoology, Patna University for the infrastructural facilities.

\section{Conflict of interest}

The authors declare that they have no conflict of interests.

\section{REFERENCES}

1. Agrahari, S. and Gopal, K. (2009). Fluctuations of certain biochemical constituents and markers enzymes as a consequence of monocrotophos toxicity in the edible freshwater fish, C. punctatus. Pesticide Biochemistry and Physiology, 94: 5-9.

2. Akhtar, M.W., Sengupta, D. and Chowdhury, A. (2009). Impact of pesticides use in agriculture: their benefits and hazards. Interdisciplinary Toxicology, 2(1):1-12.

3. Alva, S., Damodar, D., D'Souza, A., and D'Souza, U. J. (2012). Endosulfan induced early pathological changes in vital organs of rat: a biochemical approach. Indian Journal of Pharmacology, 44(4): 512-515.

4. Arjmandi, B.H., Ahn, J., Nathani, S. and Reeves, R.D. (1992). Soluble dietary fiber and cholesterol affect serum cholesterol concentration, hepatic portal venous shortchain fatty acid concentrations and fecal sterol excretion in rats. Journal of Nutrition, 122: 246-253.

5. ATSDR (2000). Toxicological Profile for Endosulfan. Agency of Toxic Substances and Disease Registry (ATSDR).

6. Bhushan, P.B., Singh, M.K., and Rani, M. (2002). Dimethoate and monocil toxicity on the concentration of protein and amino acid in serum and liver of Channa punctatus. Nature Environment and Pollution Technology, 1: 147150.

7. Coutselinis, A., Kentarchou, P., and Boukis, D. (1976). Separation and identification of the insecticide "Endosulfan" from biological materials. Forensic Science, 8(3) : 251-254. https://doi.org/10.1016/0300-9432 (76)90139-4.

8. Cuvelier, M.E., H. Richard and C. Berset, (1992). Comparison of the antioxidative activity of some acid-phenols: Structure-activity relationship. Bioscience, Biotechnology and Biochemistry. 56: 324-325.

9. Deokar, A., B. (1998) In: Manav DS (eds) Medicinal plants grown at Rajegaon. Vikas Foundation, Pune, pp 48-49.

10.Devi, P.U., Sharada, A.C., Solomon, F.E., Kamath, M.S. (1992). In vivo growth inhibitory effect of Withania somnifera (Ashwagandha) on a transplantable mouse tumour, Sarcoma 180. Indian Journal of Experimental Biology.30:169-172.

11.Di Rosa, M., Giroud, J. P., \& Willoughby, D. A. (1971). Studies on the mediators of the acute inflammatory response induced in rats in different sites by carrageenan and turpentine. The Journal of Pathology, 104(1): 15-29. https://doi.org/10.1002/path.1711040103.

12.Dongmo, O., Epoh, N. J., Tadjoua, H. T., Yousuf, S., Telefo, P. B., Tapondjou, L. A., and Choudhary, M. I. (2019). Acute and sub-acute toxicity of the aqueous extract from the stem bark of Tetrapleura tetrapteura Taub. (Fabaceae) in mice and rats. Journal of Ethnopharmacology, 236: 4249. https://doi.org/10.1016/j.jep.2019.02.026.

13.Duangjai, A., and Saokaew, S. (2018). Inhibitory effects of Tiliacora triandra (Colebr.) Diels on cholesterol absorption. Journal of Complementary and Integrative Medicine, 16 (1),/j/jcim.2019.16.issue-1/jcim-2017-0169/jcim-2017-016 9.xml. https://doi.org/10.1515/jcim-2017-0169.

14.Duangjai, A., Nuengchamnong, N., Lee, L. H., Goh, B. H., Saokaew, S., and Suphrom, N. (2019). Characterisation of an extract and fractions of Azadirachta indica flower on cholesterol lowering property and intestinal motility. Natu- 
ral Product Research, 33(10): 1491-1494. https:// doi.org/10.1080/14786419.2017.14163.

15.Ebihara, K., and Schneeman, B. O. (1989). Interaction of bile acids, phospholipids, cholesterol and triglyceride with dietary fibers in the small intestine of rats. The Journal of nutrition, 119(8), 1100-1106. https://doi.org/10.1093/jn/11 9.8.1100.

16.El-Shenawy N. S. (2010). Effects of insecticides fenitrothion, endosulfan and abamectin on antioxidant parameters of isolated rat hepatocytes. Toxicology in vitro: an international journal published in association with BIBRA, 24(4), 1148-1157. https://doi.org/10.1016/j.tiv.2010.03.001.

17. EPA (2002), Reregistration Eligibility Decision for Endosulfan, November.

18.Gad, N.S., and Saad, A.S. (2008). Effect of environmental pollution by phenol on some physiological parameters of Oreochromis niloticus. Global Veterinary. 2 (6): 312-319.

19.Gupta, P.K., (2004) Pesticide exposure-Indian scene. Toxicology. 198:83-90.

20.Helle, R.A, Marie, V.A, Thomas, H.R, Marianne, G.I, Eva, C.B.J. (2002). "Effects of Currently Used Pesticides in Assays for Estrogenicity, Androgenicity, and Aromatase Activity in Vitro". Toxicology and Applied Pharmacology. 179 (1): 1-12.

21. Hincal, F., Gurbay, A., Giray, B. (1995). Induction of lipid peroxidation and alteration of glutathione redox status by endosulfan. Biology of Trace Elements Research 47:321326.

22.Ikeda, I., and Sugano, M. (1998). Inhibition of cholesterol absorption by plant sterols for mass intervention. Current Opinion in Lipidology, 9(6), 527-531. https://doi.or g/10.1 097/00 041433-199812000-00003.

23.Jayaraj, R., Megha, P., and Sreedev, P. (2016). Organochlorine pesticides, their toxic effects on living organisms and their fate in the environment. Interdisciplinary Toxicology, 9(3-4): 90-100.

24.Jenkins, J.C., Chojnacky, D.C., Heath, L.S., Birdsey, R.A. (2003) National-scale biomass estimation for United States tree species, Forensic Science, 49: 12-35.

25.Kobliakov, V. A., Somova, O. G., Kondalenko, V. F., Ostashkina, N. M., Kandyba, A. G., Dubovaya, T. K., \& Dyatlovitskaya, E. V. (2001). Differences in lipid composition and proliferative activity of rat hepatoma-27 depending on the target organ. Biochemistry. Biokhimiia, 66(6), 603-607. https://doi.org/10.1023/a:1010294911682.

26.Kumar, A., Kumar, R, Rahman, MS., Iqubal, A., Anand, G., Niraj, P.K. and. Ali, M. (2015). Phytoremedial effect of Withania somnifera against arsenic-induced testicular toxicity in Charles Foster Rats. Avicenna Journal of Phytomedicine, 5 (4): 355-364.

27.Lee, I., Eriksson, P., Fredriksson, A., Buratovic, S., Viberg H. (2015). Developmental neurotoxic effects of two pesticides: Behavior and neuroprotein studies on endosulfan and cypermethrin. Toxicology. 335:1-10.

28.Lehninger, A.L. (1975). Biochemistry, 2nd ed. Werth Publ. Inc., New Work.

29.Mamo, J.C.L., Hirano, T., James, L., Szeto, L., Steiner, G. (1991). Partial characterization of the fructose-induced defect in very-low-density lipoprotein triglyceride metabolism. Metabolism. 40, 888-893.

30.Miettinen, T.A., Gylling, H. (1999). Regulation of choles- terol metabolism by dietary plant sterols. Current Opinion in Lipidology.10, 9-14.

31.Mirjalili, M. H., Moyano, E., Bonfill, M., Cusido, R. M., and Palazón, J. (2009). Steroidal lactones from Withania somnifera, an ancient plant for novel medicine. Molecules (Basel, Switzerland), 14(7), 2373-2393. https:// doi.org/10.3390/molecules14072373.

32.Mohamed, F.A.S., and Gad, N.S. (2008). Environmental pollution-induced biochemical changes in tissues of Tilapia zillii, Solea vulgaris and Mugil capito from Lake Qarun, Egypt. Global Veterinary, 2: 327-336.

33.Moundras, C., Behr, S.R., Remesy, C., Demigne, C. (1997). Fecal losses of sterols and bile acids induced by feeding rats guar gum are due to greater pool size and liver bile acid secretion. Journal of Nutrition. 127: 10681076.

34.Oliveira, J. M., Brinati, A., Miranda, L., Morais, D. B., Zanuncio, J. C., Gonçalves, R. V., Peluzio, M., and Freitas, M. B. (2017). Exposure to the insecticide endosulfan induces liver morphology alterations and oxidative stress in fruit-eating bats (Artibeus lituratus). International Journal of Experimental Pathology, 98(1): 17-25. https://doi.org/1 0.1111/iep. 12223.

35.Pant, J., and Singh, T. (1983). Induction of metabolic dysfunction by carbamate and organ phosphorus compounds in a fish, Puntius conchonius. Pesticide Biochemistry and Physiology. 20: 294-298.

36.Pimentel, D. (1995). Pesticides reaching target pests: Environmental impacts and ethics. Journal of Agriculture and Environment Ethics 8(1): 17-2.

37.Pradhan, S., Pandey, N., Phadke, R. V., Kaur, A., Sharma, K., and Gupta, R. K. (1997). Selective involvement of basal ganglia and occipital cortex in a patient with acute endosulfan poisoning. Journal of the Neurological Sciences, 147(2), 209-213. https://doi.org/10.1016/s0022-510x (96)05345-2.

38.Pratte, M. A., Nanavati, K. B., Young, V., and Morley, C. P. (2014). An alternative treatment for anxiety: a systematic review of human trial results reported for the Ayurvedic herb ashwagandha (Withania somnifera). Journal of alternative and complementary medicine (New York, N.Y.), 20 (12), 901-908. https://doi.org/10.1089/acm.2014.0177.

39.Rai, M., Jogee, P. S., Agarkar, G., and dos Santos, C. A. (2016). Anticancer activities of Withania somnifera: Current research, formulations, and future perspectives. Pharmaceutical Biology, 54(2): 189-197. https:// doi.org/10.3109/13880209.2015.102777.

40. Rajamanickam, V., Muthuswamy, N. (2008). Effect of heavy metals induced toxicity on metabolic biomarkers in common carp (Cyprinus Carpio L.). Maejo International Journal of Science and Technology. 2: 192-200.

41.Rajendran, S. (2003). Environment and health aspects of pesticides use In Indian agriculture in Proceedings of the Third International Conference on Environment and Health, Chennai, India, 5-17 December 2003. Martin J.Bunch, V. Madha Suresh and T. Vasantha Kumaran, eds., $353-373$.

42.Saravanan, V.S., M.R. Kumar and T.M. Sa. (2011). Microbial zinc solubilization and their role on plants. In: D.K. Maheshwari (ed.), Bacteria in Agrobiology: Plant nutrient management. Springer, Berlin; pp.47-63. 
43.Satyavati, G.V, Raina, M.K, Sharma. M. (1976) In: Medicinal plants of India, Vol. I, Indian Council of Medical Research, New Delhi; p. 377 -9.

44.Shell, E.W. (1961). Chemical composition of blood of small mouthbass. Res. Rep. U.S. Wildl. Serv., 57:1-36.

45.Sood, S., Arora, B., Bansal, S., Muthuraman, A., Gill, N. S., Arora, R., Bali, M., and Sharma, P. D. (2009). Antioxidant, anti-inflammatory and analgesic potential of the Citrus decumana L. peel extract. Inflammopharmacolo gy, 17(5):267274.https://doi.org/10.1007/s10787-009-00 15-y.

46.Suhail, M., Athar, J. and Rizvi, S.I. (1988). Lipid changes in red cell membrane in leukemia., Indian Journal of Medical Research, 88:350- 355.

47.Teymouri, M., Mashreghi, M., Saburi, E., Hejazi, A., and Nikpoor, A. R. (2019). The trip of a drug inside the body: From a lipid-based nanocarrier to a target cell. Journal of Controlled Release, 309: 59-71. https://doi.org/10.1016/ j.jconrel.2019.07.027.

48.USEPA (2010). Endosulfan. The Health Effects Division's Human Health Risk Assessment. EPA DP Barcode: D372569. June 2010.134 pages. Docket No.: EPA-HQOPP-2002-0262-0178; http://www.regulations.gov.

49.Vahouny, G.V., Tombes, R., Cassidy, M.M., Kritchevsky, D., Gallo, L.L. (1980) Dietary fibers: V. Binding of bile salt, phospholipids and cholesterol from mixed micelles by bile acid sequestrants and dietary fibers. Lipids. 15: 1012-1018.

50.Vandenberg, L. N., Najmi, A., and Mogus, J. P. (2020). Agrochemicals with estrogenic endocrine disrupting properties: Lessons Learned?. Molecular and Cellular Eendocrinology, 110860.

51.Vinson, J. A., Su, X., Zubik, L., and Bose, P. (2001). Phenol antioxidant quantity and quality in foods: fruits. Journal of Agricultural and Food Chemistry, 49(11): 5315-5321. https://doi.org/10.1021/jf0009293.

52. Visavadiya, N. P., and Narasimhacharya, A. V. (2007). Hypocholesterolemic and antioxidant effects of Withania somnifera (Dunal) in hypercholesteremic rats. Phytom edicine: International Journal of Phytotherapy and Phytopharmacology, 14(2-3), 136-142.

53.WHO (2005). The WHO Recommended Classification of Pesticides by Hazard. World Health Organization

54.Wilson, W. W., Shapiro, L. P., Bradner, J. M., and Caudle, W. M. (2014). Developmental exposure to the organochlorine insecticide endosulfan damages the nigrostriatal dopamine system in male offspring. Neurotoxicology, 44: 279-287. https://doi.org/10.1016/j.neuro.2014.07.008.

55.Wu, C., Tian, Y., Yu, J., Zhang, R., Zhang, X., and Guo, P. (2019). The Pandanus tectorius fruit extract (PTF) modulates the gut microbiota and exerts antihyperlipidaemic effects. Phytomedicine: International Journal of Phytotherapy and Phytopharmacology, 58, 152863. https://doi.org/10.1016/j.phymed.2019.152863.

56. Xu, D., Liu, T., Lin, L., Li, S., Hang, X., and Sun, Y. (2017). Exposure to endosulfan increases endothelial permeability by transcellular and paracellular pathways in relation to cardiovascular diseases. Environmental Pollution (Barking, Essex: 1987), 223: 111-119.

57.Yadla, M., Yanala, S. R., Parvithina, S., Chennu, K. K., Annapindi, N., and Vishnubhotla, S. (2013). Acute kidney injury in endosulfan poisoning. Saudi Journal of Kidney Diseases and transplantation: an official publication of the Saudi Center for Organ Transplantation, Saudi Arabia, 24 (3), 592-593

58.Yavuz, Y., Yurumez, Y., Kücüker, H., Ela, Y., and Yüksel, S. (2007). Two cases of acute endosulfan toxicity. Clinical toxicology (Philadelphia, Pa.), 45(5): 530-532. https:// doi.org/10.1080/15563650701365909.

59. Yekeen, T.A. and Fawole, O.O. (2011). Toxic effects of endosulfan on haematological and biochemical indices of Clarias gariepinus. Afr. J. Biotechnol. 10 (64): 1409014096. 